Louisiana State University

LSU Digital Commons

Faculty Publications

Department of Biological Sciences

7-25-2006

\title{
Phylogeny of the parasitic plant family Orobanchaceae inferred from phytochrome A
}

Jonathan R. Bennett

The Natural History Museum, London

Sarah Mathews

Harvard University

Follow this and additional works at: https://digitalcommons.Isu.edu/biosci_pubs

Recommended Citation

Bennett, J., \& Mathews, S. (2006). Phylogeny of the parasitic plant family Orobanchaceae inferred from phytochrome A. American Journal of Botany, 93 (7), 1039-1051. https://doi.org/10.3732/ajb.93.7.1039

This Article is brought to you for free and open access by the Department of Biological Sciences at LSU Digital Commons. It has been accepted for inclusion in Faculty Publications by an authorized administrator of LSU Digital Commons. For more information, please contact ir@lsu.edu. 


\title{
Phylogeny of the parasitic plant family OrobanCHACEAE INFERRED FROM PHYTOCHROME $\mathbf{A}^{1}$
}

\begin{abstract}
Jonathan R. BenNetT ${ }^{2}$ AND SARAH MATHews ${ }^{3,4}$
${ }^{2}$ Department of Botany, The Natural History Museum, Cromwell Road, London SW7 5BD UK; and ${ }^{3}$ The Arnold Arboretum, 22 Divinity Avenue, Harvard University, Cambridge, Massachusetts 02138 USA

Partial sequences of the nuclear gene encoding the photoreceptor phytochrome A (PHYA) are used to reconstruct relationships within Orobanchaceae, the largest of the parasitic angiosperm families. The monophyly of Orobanchaceae, including nonphotosynthetic holoparasites, hemiparasites, and nonparasitic Lindenbergia is strongly supported. Phytochrome A data resolve six well-supported lineages that contain all of the sampled genera except Brandisia, which is sister to the major radiation of hemiparasites. In contrast to previous plastid and ITS trees, relationships among these major clades also are generally well supported. Thus, the robust phylogenetic hypothesis inferred from the PHYA data provides a much better context in which to evaluate the evolution of parasitism within the group. Ninety-eight species of Orobanchaceae, representing 43 genera, are included and Brandisia, Bungea, Cymbaria, Esterhazya, Nesogenes, Phtheirospermum, Radamaea, Siphonostegia, and Xylocalyx are confirmed as members of Orobanchaceae. The earliest diverging lineage of hemiparasites is identified for the first time; it contains Bungea, Cymbaria, Monochasma, Siphonostegia, and the monotypic Schwalbea, which is federally endangered. This basal clade is marked by the presence of two novel introns. A second, apparently independent gain of one of these introns marks a clade of largely European taxa. There is significant rate heterogeneity among PHYA sequences, and the presence of multiple PHYA in some taxa is consistent with observed ploidy levels.
\end{abstract}

Key words: introns; Orobanchaceae; parasitism; phylogeny; phytochrome A; Scrophulariaceae.

Orobanchaceae, as redefined by Young et al. (1999), are a morphologically diverse family of predominantly herbaceous, parasitic plants. The majority of species are facultative or obligate root parasites, which may be photosynthetic (hemiparasites) or totally dependent on the host plant (holoparasites). Several genera, such as Striga, Alectra, and Orobanche, are serious agricultural pests of cereal and legume crops, particularly in the dry tropics and subtropics, where they may reduce crop yields substantially (Riches and Parker, 1995). The family has a worldwide distribution, including species from extreme northern latitudes (e.g., Pedicularis dasyantha Hadac, endemic to the European-Russian arctic; Odasz and Savolainen, 1996), but the main centers of distribution are the Mediterranean, southern Africa, the Himalayas, and western North America. Some genera are distributed over several continents, such as Euphrasia (Europe, North and South America, Oceania), Bartsia (Africa, Europe, North and South America), and Buchnera and Melasma (Africa, Asia, North and South America). Currently 89 genera, containing ca. 2061 species, are recognized in Orobanchaceae (Nickrent, 2006). Thus, Orobanchaceae are the most species-rich of parasitic angiosperm families-sizes of other families range from two to 905 species - and are of a size comparable to the order Santalales (Nickrent, 2006). A robust phylogenetic hypothesis

\footnotetext{
${ }^{1}$ Manuscript received 10 January 2006; revision accepted 5 April 2006.

The authors thank A. Colwell, J. McNeal, R. Olmstead, G. Schneeweiss, D. Tank, and A. Wolfe for useful discussions; D. Boufford, A. Colwell, Cl. dePamphilis, M. Hjertson, C. Hughes, S. Strgulc Krajsek, A. Miller, R. Nyffler, R. Olmstead, D. Tank, R. Ree, G. Schneeweiss, R. Scotland, A. Wolfe, J. Wood, and G. Yatskievych for help in obtaining DNA or tissues; E. Lesniak, D. Sachs, B. Tseng, and J. U'Ren for technical assistance, and two anonymous reviewers for comments on the manuscript. This work was supported by NSF grant DEB-0215780 and postdoctoral research fellowships from the Arnold Arboretum of Harvard University and the University of Missouri-Columbia.

${ }^{4}$ Author for correspondence (e-mail: smathews@oeb.harvard.edu)
}

for the family will enable a greater understanding of the factors, such as parasitism, that may underlie the success of Orobanchaceae and also will serve as a context in which to better understand the implications of plastid genome evolution (e.g., dePamphilis, 1995; Wolfe and dePamphilis, 1998; Bungard, 2004; Young and dePamphilis, 2000, 2005).

Orobanchaceae were traditionally circumscribed to contain only holoparasitic genera such as Orobanche, Epifagus, and Conopholis; hemiparasitic taxa were classified with nonparasites in an expanded Scrophulariaceae (e.g., Bentham, 1846, 1876; von Wettstein, 1891). However, these classifications did not deal adequately with holoparasitic taxa such as Lathraea and Hyobanche, which were placed in Scrophulariaceae by some authors on account of their bilocular gynoecia and in Orobanchaceae by others on account of their holoparasitic nature (Boeshore, 1920; Kuijt, 1969). Some authors included Orobanchaceae entirely within Scrophulariaceae (Hallier, 1903; Bellini, 1907). More recently, these relationships were investigated in a series of phylogenetic analyses of plastid sequence data (dePamphilis, 1995; dePamphilis et al., 1997; Nickrent et al., 1998; Young et al., 1999; Young and dePamphilis, 2000; Olmstead et al., 2001) and of nuclear 18S rDNA (Nickrent et al., 1998) and ITS (Wolfe et al., 2005) sequence data. Hemiparasitic species, formerly placed in Scrophulariaceae subfamily Rhinanthoideae, and Orobanchaceae were shown to comprise a monophyletic group. Parasitism is believed to have evolved once in the group, followed by multiple independent origins of holoparasitism from hemiparasitic ancestors (Young et al., 1999). Lindenbergia philippensis, from a genus of 12 nonparasitic species from northeast Africa and Asia (Hjertson, 1995) previously classified in Scrophulariaceae subfamily Antirrhinoideae (von Wettstein, 1891), was resolved as sister to the parasitic species (Nickrent et al., 1998; Young et al., 1999; Young and dePamphilis, 2000; Olmstead et al., 2001) and included in a clade definition of Orobanchaceae (Young et 
al., 1999). These molecular analyses confirmed the view that holoparasitic and hemiparasitic species are closely related, but the multiple independent losses of photosynthetic ability in the group did not support the conclusion of Boeshore (1920) that there was a single progressive degradation from autotrophs through hemiparasites to holoparasites.

Additional evidence for a close relationship between hemiparasites and holoparasites comes from studies of pollen morphology (İnceoğlu, 1982; Minkin and Eshbaugh, 1989; Abu Sbaih et al., 1994). The pollen of both holoparasites and hemiparasites is tricolpate with retipillate exine sculpturing, whereas that of nonparasitic species of Scrophulariaceae sensu von Wettstein (1891) is tricolporate with a reticulate exine (Minkin and Eshbaugh, 1989). The pollen of Lindenbergia is also tricolporate with a reticulate exine (Hjertson, 1995), but their pattern of corolla aestivation is the same as that of the parasitic species, with the abaxial lobes folded over the adaxial lobes (Brühl, 1920; Armstrong and Douglas, 1989).

Although analyses of plastid sequence data have considerably advanced our understanding of relationships and the evolution of parasitism in Orobanchaceae, the taxonomic sampling from within Orobanchaceae for these studies was limited, and there was a lack of resolution within the family. Moreover, the loss of many plastid genes from some parasitic taxa (dePamphilis and Palmer, 1990; Morden et al., 1991; Wimpee et al., 1991, 1992; Wolfe et al., 1992a-d) limits their utility as phylogenetic markers. Internal transcribed spacer data have provided insight, but they also failed to provide robust resolution of major lineages within the family (Wolfe et al., 2005). On average, protein-coding nuclear genes evolve faster than plastid and mitochondrial genes (Wolfe et al., 1987) and thus may contain variation suitable to address unresolved relationships within Orobanchaceae. In this study we utilize partial sequences from a nuclear gene, phytochrome $\mathrm{A}$, to identify the composition of the major lineages within the family and address relationships among them. Phytochromes regulate growth and developmental responses to light signals in the red and far-red regions of the visible spectrum (Smith, 2000), some of which are significantly altered in parasites. Thus, while our focus is phylogenetic, the accumulation of phytochrome data sets will provide an important resource not only for investigation of molecular evolution at nuclear loci in parasites to complement studies of plastid genes (dePamphilis, 1995; Wolfe and dePamphilis, 1998; Young and dePamphilis, 2000, 2005; Bungard, 2004; Barbrook et al., 2006), but also for understanding sequence level changes that may have functional implications in nonphotosynthetic plants.

The phytochrome gene family contains five members in Arabidopsis, PHYA-PHYE (Clack et al., 1994), which have distinct and overlapping functions (Møller et al., 2002; Franklin et al., 2003a, b; Halliday and Whitelam, 2003; Monte et al., 2003; Sharrock et al., 2003). Phylogenetic analyses indicate that a gene duplication near the origin of seed plants gave rise to two major lineages, one comprising homologues of Arabidopsis PHYA and PHYC and the other of $P H Y B, P H Y D$, and PHYE (Mathews et al., 1995; Mathews and Sharrock, 1997). Genes $P H Y A$ and $P H Y C$ diverged from one another prior to the origin of angiosperms, where they form monophyletic gene lineages (Sharrock and Quail, 1989; Mathews et al., 1995; Mathews and Sharrock, 1997) that encode divergent functions (Sharrock and Mathews, 2006). The loss of PHYA has not been detected in any species and the loss of PHYC has been documented in a single taxon, Populus trichocarpa Torr.
\& A. Gray (Howe et al., 1998). Duplications have been detected in the PHYA lineage within Fabaceae (Lavin et al., 1998) and Caryophyllaceae (Li and Chinnappa, 2003).

Most phytochrome genes isolated from green plants (land plants and green algae) have a high degree of amino acid sequence and structural similarity (Mathews et al., 1995; Montgomery and Lagarias, 2002), that makes alignment of coding sequences straightforward. Nevertheless, paralogous PHY loci from angiosperms have distinctive motifs that allow them to be easily distinguished and that facilitate locus-specific amplification protocols. Phytochrome exon sequences have been useful in phylogenetic studies of Poaceae (Mathews and Sharrock, 1996; Mathews et al., 2000), Fabaceae (Lavin et al., 1998), Celastraceae (Simmons et al., 2001), Phyllanthaceae (Samuel et al., 2005), Malpighiaceae (Davis et al., 2002), and monocots (Duvall et al., in press), and in resolving relationships among basal angiosperms (Mathews and Donoghue, 1999, 2000). Results from phylogenetic analyses of an approximately 1.8 -kilobase $(\mathrm{kb})$ region of phytochrome A (PHYA) provide new insight into relationships within Orobanchaceae, and levels of support for clades identified in other analyses are higher than previously have been achieved. Additionally, we discovered the insertion of novel introns in PHYA that may serve as useful markers for some clades within Orobanchaceae, particularly of a basal clade that includes previously unsampled and/or unplaced genera.

\section{MATERIALS AND METHODS}

Taxon sampling and outgroup selection-Partial PHYA sequences were obtained from 98 species of Orobanchaceae (Appendix), including multiple accessions of some genera (e.g., Pedicularis, Euphrasia, Orobanche). The data set comprised representatives of all the major clades inferred from previous analyses of Orobanchacaeae (dePamphilis, 1995; dePamphilis et al., 1997; Nickrent et al., 1998; Young et al., 1999; Young and dePamphilis, 2000; Olmstead et al., 2001; Wolfe et al., 2005). Forty-three of the 89 genera currently recognized in Orobanchaceae (Nickrent, 2006) were included. Bungea, Cymbaria, Escobedia, Esterhazya, Monochasma, Nesogenes, Odontites, Radamaea, Siphonostegia, and Xylocalyx are here included for the first time in a molecular phylogenetic study.

Several species of Lamiales were also included in the maximum parsimony (MP) analyses (families are given according to Olmstead et al. [2001] and Oxelman et al. [2005]): Ajuga reptans (Lamiaceae), Alonsoa sp. (Scrophulariaceae), Aptosimum pumilum (Scrophulariaceae), Chelone obliqua (Plantaginaceae), Glechoma hederacea (Lamiaceae), Paulownia tomentosa (Paulowniaceae), Penstemon cobaea (Plantaginaceae), Scrophularia arguta (Scrophulariaceae), and Strobilanthes attenuata (Acanthaceae), and trees were rooted with Solanum tuberosum (Solanaceae). To reduce computation time only Paulownia and Solanum were included as outgroups in the maximum likelihood (ML) analyses.

DNA extraction, cloning and sequencing - Total genomic DNA was extracted using the DNAeasy Plant Mini Kit protocol (QIAGEN, Valencia, California, USA) from fresh or dried tissue. Phytochrome fragments were amplified and cloned using the protocols detailed in Mathews et al. (2000). In some cases, PHYA products were doublets or triplets that were cloned separately, with two clones being sequenced from each fragment. From a subset of species, up to 12 clones were screened. From most accessions, a 2.0-2.5-kb region including intron I was successfully amplified using the forward primer $212 \mathrm{f}$ and reverse primer a832r.2 (Table 1). For eight sequences, two smaller fragments were amplified using different combinations of the primers listed in Table 1 and assembled in Sequencher (GeneCodes, Ann Arbor, Michigan, USA). In four cases, there was substantial overlap (120-555 base pairs [bp]) and the fragments had $>99 \%$ identity. In the other four cases the separate fragments did not overlap, but they were sister sequences in preliminary analyses. They were combined into a single terminal for subsequent analyses. 
Phylogenetic analyses-Exon boundaries were inferred based on the conserved gene structure of land plant phytochromes, and the introns were removed before the coding sequences were aligned manually. A small variable region near to the chromophore attachment site was difficult to align unambiguously and was deleted. Autapomorphic gaps also were deleted, leaving a final matrix of 1824 nucleotide sites, of which 1141 (ca. 62\%) were phylogenetically informative in the parsimony analysis. The 121 sequences analyzed in the parsimony analysis represented 98 species of Orobanchaceae and 11 outgroup species.

Parsimony analyses using PAUP* version 4.0b10 (Swofford, 2002) comprised 1000 random-addition replicates with tree-bisection-reconnection (TBR) branch swapping and MULPARS on so that multiple most parsimonious trees are saved during branch swapping. Gaps were scored as missing data. One thousand bootstrap replicates were performed using 100 random-addition replicates and MULPARS off following the strategy of DeBry and Olmstead (2000).

Maximum likelihood analyses were conducted using PAUP* 4.0b10 (Swofford, 2002). The general time-reversible model (Rodríguez et al., 1990) with rate variation among nucleotides following a discrete gamma distribution and assuming a proportion of invariant sites was chosen by a hierarchical likelihood ratio test as implemented in Modeltest version 3.7 (Posada and Crandall, 1998). Model parameters were set to those estimated by Modeltest 3.7. Tree-bisection-reconnection branch-swapping was employed on a starting tree obtained using random stepwise addition. One hundred bootstrap replicates were analyzed using nearest-neighbor interchange (NNI) branch swapping and AsIs stepwise addition.

Templeton and Shimodaira-Hasegawa tests - To explore the alternative placements of the basalmost clades, the nonparametric Templeton test (Larsen, 1994) and the likelihood-based Shimodaira-Hasegawa test (SH test; Shimodaira and Hasegawa, 1999) were implemented in PAUP* 4.0b10. We compared the trees obtained from the parsimony analysis (clade I sister to the rest of Orobanchaceae; Fig. 1) with trees obtained from constrained analyses in which (1) clades I and II are sister to the rest of Orobanchaceae (the topology obtained in the ML analysis, Fig. 2) and (2) clade II is sister to the rest of Orobanchaceae. For the SH test, the test distribution was obtained using the reestimated log likelihoods (RELL) approximation with 1000 nonparametric bootstrap replicates.

\section{RESULTS}

Phytochrome A sequence characteristics-A single PHYA sequence was amplified and cloned from most taxa, but two or more PHYA sequences were cloned from Castilleja sulphurea, Escobedia grandiflora, Euphrasia stricta, Lathraea clandestina, L. squamaria, Melasma scabrum, Striga linearifolia, $X y l o c a l y x$ asper, and $X$. carterae.

Most PHYA fragments spanned a region that included intron I, located at amino acid position 745 of the alignment of Mathews et al. (1995). Intron I was present in all of these sequences and was of variable length (Appendix). Additionally, PHYA coding sequences from some species were interrupted by up to two additional putative introns. The first, intron A, is located at amino acid position 482, downstream of the chromophore-binding site (amino acid position 374) and was found in all species of clades II and V (Figs. 1-3). The second novel intron, intron B at position 575, was found only in species of clade II.

There was large length variation between the same introns from different species (Appendix), and it was impossible to unambiguously align the sequences across the whole family. Alignment of introns from species across major clades was also difficult. However, it was possible to align intron sequences from species of the same genus (e.g., within Castilleja or Rhinanthus). Three intron sequences, intron B from Schwalbea americana and intron I from Odontites himalayicus and Glechoma purpurea, did not have the canonical 5' GT and 3'
TABLE 1. Primer sequences used in this study for the amplification of PHYA.

\begin{tabular}{ll}
\hline \hline Forward Primers $\left(5^{\prime}-3^{\prime}\right)$ & \\
212f & TCWGGNAARCCNTTYTAYGC \\
a230f.ORO & GAYTTYGAGCCYGYNAADCCYYAYG \\
a236f.ORO & CCYYAYGAKGTBCCHATGASYGC \\
377f & CARTAYATGGCNAAYTGG \\
444f & CARGTNTTYGCHATHCAYG \\
a624f.ORO & GAYTWYGARATGGAYGCRAT \\
Reverse Primers $\left(5^{\prime}-3^{\prime}\right)$ & \\
432r & \\
444r & CRCANGCRTANCKNARNGGRWANGG \\
a575r.ORO & CRTGGATGGCRAANACYTG \\
a624r.ORO & KCHGTGTKNGACCKRAACCA \\
a678r & ATYGCRTCCATYTCRSARTC \\
a788r.ORO & GTYTCMATBARDCKRACCATYTC \\
a832r.2 & GHGCDATGAARCAYRCKCC \\
\hline
\end{tabular}

AG that are recognized by the spliceosome. Schwalbea and Odontites had a single base substitution at the $5^{\prime}$ end to GA and GC, respectively, and Glechoma had a substitution at the $3^{\prime}$ end to AA. If these introns were not spliced correctly a frame shift or stop codon would result in an altered protein product.

Phylogenetic analyses-Parsimony analysis yielded four equally parsimonious trees of length 9754 that differed only in the relationships among Castilleja rubicundula, C. tenuifolia, and Triphysaria pusilla, and among the outgroups. A schematic tree showing the relationships between the major clades from the parsimony analysis is shown in Fig. 1. The topology of the ML tree (Figs. 2-3) was nearly identical to that of the parsimony tree, except that the ML tree unites clades I and II, while the parsimony tree places them as successive sister taxa to the rest of the family. Relationships within clade VI also differ between the two analyses, although these do not receive bootstrap support in either analysis. Bootstrap support for most nodes is similar between the parsimony and ML trees, and only 12 nodes differed by more than 10 percentage points;

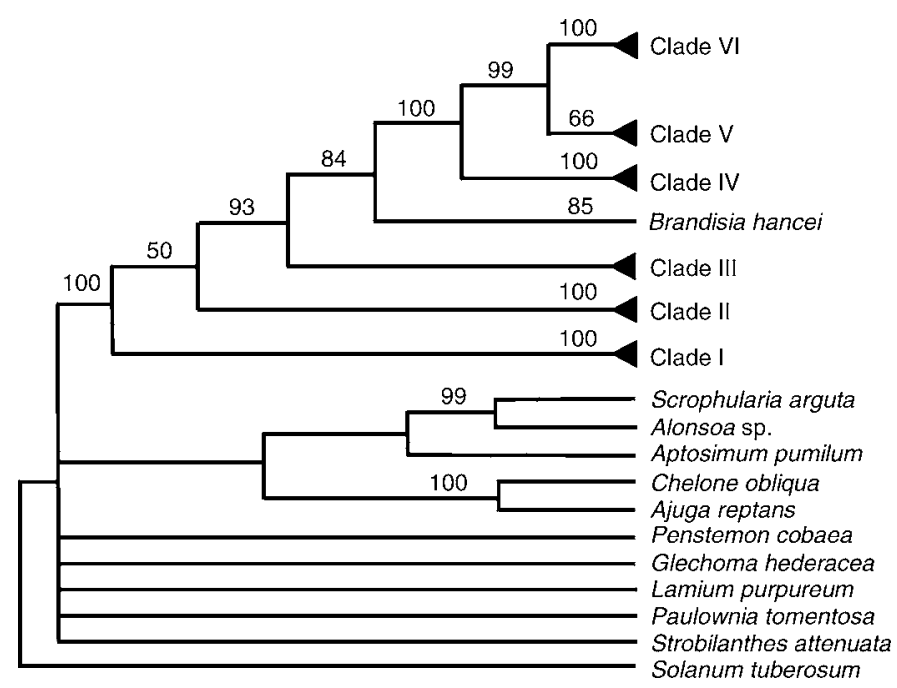

Fig. 1. Phylogeny of Orobanchaceae inferred from a parsimony analysis of $P H Y A$. Species relationships within the major clades are not shown. Parsimony bootstrap values are indicated. 


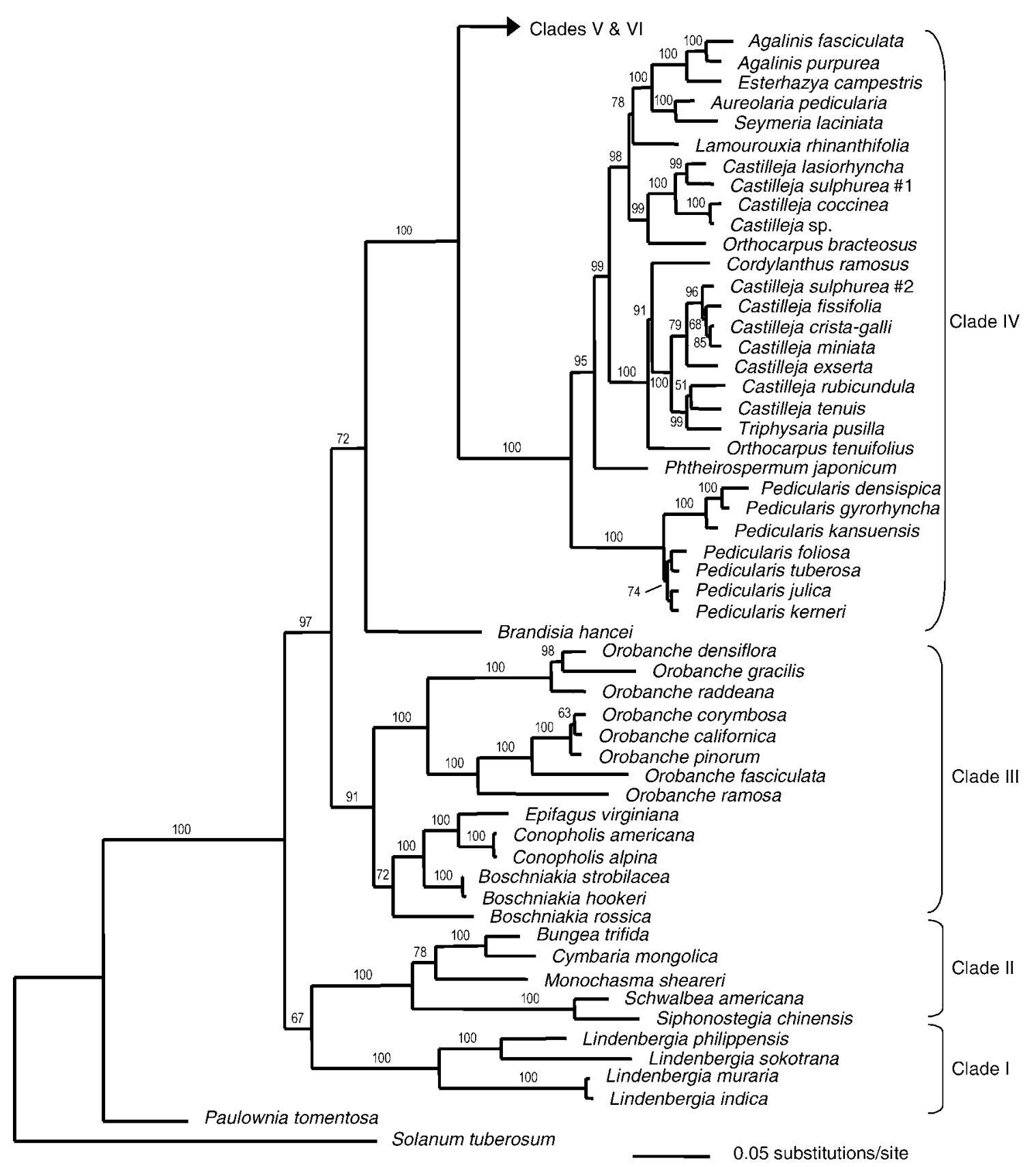

Fig. 2. Basal portion of the maximum likelihood tree derived from an analysis of $P H Y A$ under the GTR $+\mathrm{I}+\Gamma$ model of sequence evolution $(-\operatorname{lnL}=$ 40446.88) showing bootstrap support values. Branch lengths are proportional to the number of changes along each branch and major clades referred to in the text are indicated.

we report both MP and ML bootstrap values for the nodes discussed in the text below.

The monophyly of Orobanchaceae sensu Young et al. (1999) is well supported in both MP and ML analyses with bootstrap (BS) percentages of $100 \%$. Six major clades plus Brandisia hancei are consistently resolved within Orobanchaceae in all analyses (Figs. 1-3). Clades I and II are well supported as monophyletic in both the MP and ML analyses (100\% BS), and species relationships within these clades also receive high support. However, there is only weak support for the position of clade I as sister to all other Orobanchaceae in the MP analysis (50\% BS; Fig. 1). In the ML tree (Fig. 2), clade I is sister to clade II $(67 \% \mathrm{BS})$, which together are sister to the rest of the family with high BS (100\%). We conducted a Bayesian analysis to determine whether an ML-based search using a codon model would yield a tree consistent with the ML tree inferred using a nucleotide model. The Bayesian tree also unites clades I and II, with a posterior probability of 0.92 (data not shown). The alternative placements of clades I and II from the constrained analyses cannot be rejected at a level of significance $\leq 0.2$ by the Templeton and $\mathrm{SH}$ tests (data not shown). 


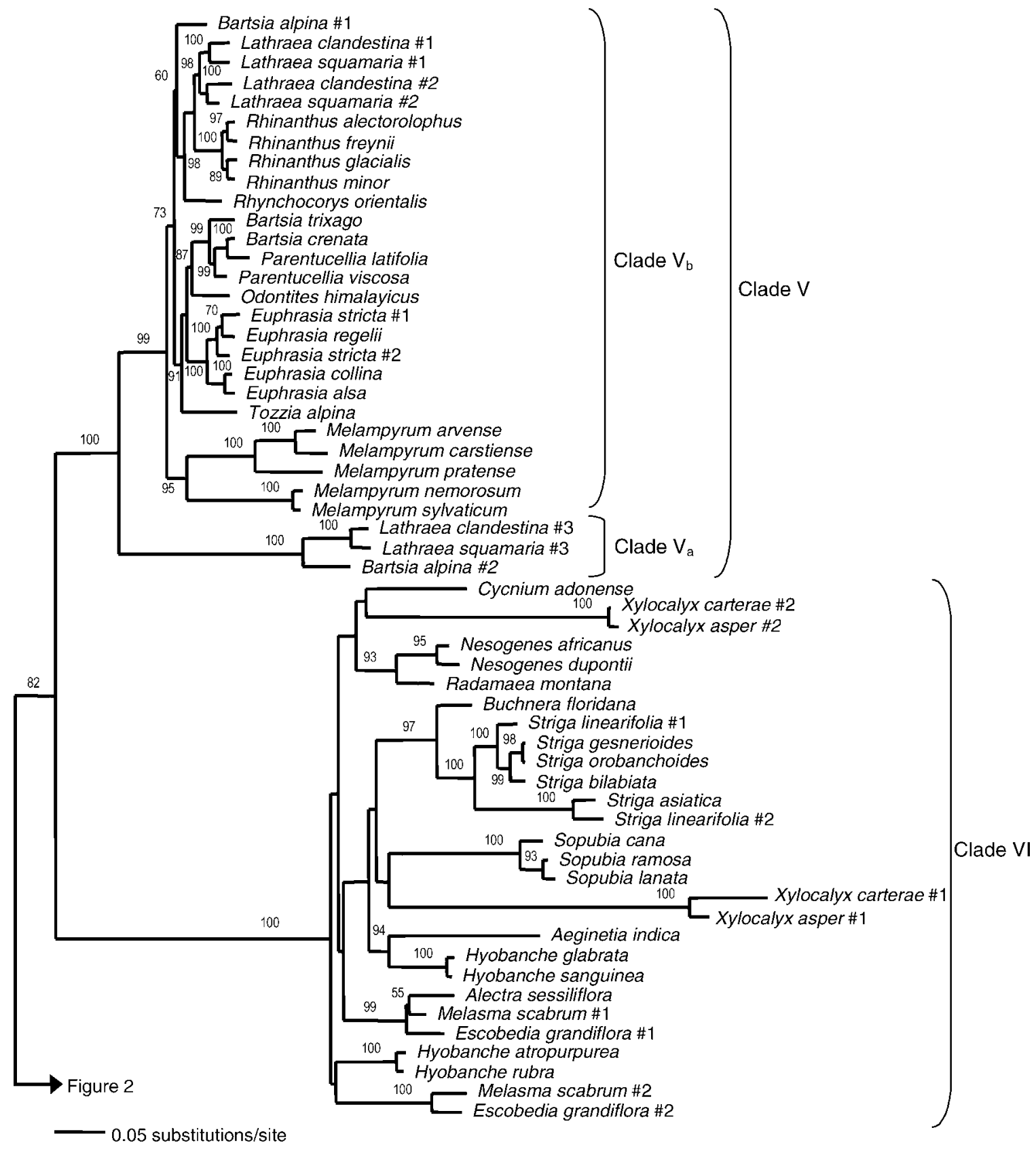

Fig. 3. Distal portion of the maximum likelihood tree. Branch lengths are proportional to the number of changes along each branch and major clades referred to in the text are indicated.

The next diverging clade, clade III, contains most of the holoparasitic species and is supported in both MP and ML analyses (85\% MPBS, 91\% MLBS). Within this clade Orobanche is monophyletic (100\% MPBS and MLBS) and is sister to a clade of Epifagus, Conopholis, and Boschniakia (87\% MPBS, $72 \%$ MLBS). Brandisia hancei is the next lineage sister to the rest of the family (84\% MPBS, $72 \%$ MLBS).

The remaining species fall into a large clade (100\% MPBS and MLBS) containing clades IV, V, and VI. Clades IV and VI receive bootstrap support of $100 \%$ in both MP and ML analyses. Clade $\mathrm{V}$ receives only $66 \% \mathrm{BS}$ support in the MP analysis, but $100 \%$ BS support in the ML analysis. Clades V and VI are supported as sister taxa (99\% MPBS, 82\% MLBS). Clade IV is well supported as sister to clades V and VI in both the MP and ML analyses (100\% BS).

Within clade IV, Pedicularis is resolved as monophyletic with $100 \%$ BS support in both MP and ML analyses and is sister to the remaining species. Within Pedicularis, two monophyletic groups are resolved, one containing the Asian species $P$. densispica, $P$. gyrorhyncha, and P. kansuensis (100\% MPBS and MLBS) and the other containing four European species, $P$. foliosa, $P$. tuberosa, $P$. julica, and $P$. kerneri (96\% MPBS, 74\% MLBS). Phtheirospermum japoni- 
cum is resolved as sister to the remaining species. Castilleja and Orthocarpus PHYA sequences occur in two clades, with Cordylanthus and Triphysaria on the one hand and Lamourouxia, Seymeria, Agalinis, Aureolaria, and Esterhazya on the other. Each of the two Castilleja clades contains one of the two PHYA sequences from $C$. sulphurea, suggesting that the polyphyly of Castilleja in the PHYA tree results from differential sampling of paralogs. There is $100 \%$ BS support for a clade of Agalinis, Aureolaria, Esterhazya, and Seymeria in both the MP and ML analyses.

From some clade V taxa (Lathraea clandestina, L. squamaria, Euphrasia stricta, and Bartsia alpina), multiple copies of PHYA were detected. The two sequences from $E$. stricta are not sister in the Euphrasia clade, suggesting that other Euphrasia species may also contain additional PHYA copies that were not detected in our study. Three sequences from L. squamaria, L. clandestina, and B. alpina form a wellsupported monophyletic group (clade $\mathrm{V}_{\mathrm{a}}$ ) in both the MP and ML analyses $(100 \% \mathrm{BS})$ that is separated from clade $\mathrm{V}_{\mathrm{b}}$ by a long branch (Fig. 3). Bootstrap support for clade $\mathrm{V}_{\mathrm{b}}$ is high (100\% MPBS, 99\% MLBS), suggesting that the sequences of clade $\mathrm{V}_{\mathrm{a}}$ represent a divergent copy that was not detected in the other species that were sampled. Support for clade V as a whole, including both $\mathrm{V}_{\mathrm{a}}$ and $\mathrm{V}_{\mathrm{b}}$, is only $66 \%$ in the MP analysis but $100 \%$ in the ML analysis.

Within clade $\mathrm{V}_{\mathrm{b}}$, species relationships are generally well resolved. The five species of Melampyrum form a monophyletic group (87\% MPBS, 95\% MLBS) that is sister to the rest of the clade (100\% MPBS, 99\% MLBS). Rhinanthus is monophyletic (100\% MPBS and MLBS) and is sister to four sequences from Lathraea clandestina and L. squamaria. Bartsia alpina is sister to a group of Rhinanthus, Lathraea, and Rhynchocorys (in clade $\mathrm{V}_{\mathrm{b}}$ only), but this relationship does not receive much support (52\% MPBS, 60\% MLBS). Euphrasia also is monophyletic (100\% MPBS and MLBS). Bartsia trixago from Europe and $B$. crenata from Bolivia are paraphyletic to Parentucellia and are separate from B. alpina.

Relationships within clade VI receive less support than relationships within other clades, and they differ in the MP and ML trees. Multiple PHYA sequences were cloned from Melasma scabrum, Escobedia grandiflora, Xylocalyx asper, $X$. carterae, and Striga linearifolia. The monophyly of Sopubia and Striga is well supported (99-100\% MPBS and MLBS), and Radamaea montana is supported as sister to the two species of Nesogenes (99\% MPBS, 93\% MLBS).

\section{DISCUSSION}

This is the most extensive sampling of Orobanchaceae to date, representing a broad geographic and taxonomic range of taxa and including several genera that have not been included in previous phylogenetic studies. PHYA sequence data provide greater evidence of phylogenetic structure within the family than have analyses of plastid (dePamphilis, 1995; dePamphilis et al., 1997; Nickrent et al., 1998; Young et al., 1999; Young and dePamphilis, 2000; Olmstead et al., 2001), ITS (Wolfe et al., 2005), and nuclear $18 \mathrm{~S}$ rDNA sequence data (Nickrent et al., 1998). Sixty-seven percent of the nodes in the parsimony bootstrap analysis and $71 \%$ in the maximum likelihood bootstrap analysis receive bootstrap support of over $90 \%$. Support is greatest towards the terminal portions of the tree, although many of the nodes along the spine are also well supported.

The monophyly of Orobanchaceae, containing holoparasites, hemiparasites, and nonparasitic species, is well supported (100\% MPBS and MLBS). This corroborates previous analyses of plastid and nuclear ribosomal DNA sequences and provides further evidence that the traditional classifications of Orobanchaceae and Scrophulariaceae (e.g., Bentham, 1846, 1876) do not reflect the phylogenetic relationships of these families.

The PHYA data support six major clades (66-100\% MPBS, 91-100\% MLBS). Relationships among these clades also are supported by the PHYA data. Clades V and VI are sister taxa, and these are sister to clade IV. The position of Brandisia as the sister taxon to these three clades receives less support, but the position of the completely holoparasitic clade III as sister to the majority of the hemiparasitic and holoparastic taxa is well supported. Thus, the major exception to the almost universal support for broad phylogenetic structure within Orobanchaceae in the PHYA tree is at the base of the tree, where the PHYA data are ambiguous as to the branching order of clades I (the nonparasitic genus, Lindenbergia) and II (the earliest diverging clade of hemiparasites) (cf. Figs. 1 and 2).

These results differ from those obtained in previous studies. An analysis of combined plastid data supported a clade of mostly European genera that is consistent with $P H Y A$ clade $\mathrm{V}$ and an African clade that is consistent with PHYA clade VI (the tropical and subtropical genera), but provided low support for a clade corresponding to PHYA clade III (Orobanche and related holoparasites); Castilleja and Pedicularis were not united in the plastid tree as they are in PHYA clade IV, and bootstrap support for relationships among major clades was below 50\% (Young et al., 1999). However, the one species of the nonparasitic Lindenbergia that was included was well supported as the sister taxon of the remaining species, which included the monotypic Schwalbea (Young et al., 1999). An analysis of ITS data also supported clades that are consistent with PHYA clades V and VI, but provided only low support for a clade corresponding to PHYA clade IV. Orobanche and holoparasitic relatives were resolved with bootstrap support below $50 \%$ as paraphyletic to the ITS African-SW Asian clade, and the position of Lindenbergia as sister to all parasites received low support (Wolfe et al., 2005). As with the plastid data, relationships among the major clades received bootstrap support below 50\%, except for a sister group relationship between clades that correspond to PHYA clades IV (Castilleja, Pedicularis, and relatives) and V (mostly European genera), which received $71 \%$ MP bootstrap support (Wolfe et al., 2005).

The basal branches of Orobanchaceae-Recent molecular studies have placed Lindenbergia philippensis as sister to the rest of Orobanchaceae but they included no other species of Lindenbergia (Nickrent et al., 1998; Young et al., 1999; Young and dePamphilis, 2000; Olmstead et al., 2001; Wolfe et al., 2005). This would suggest that parasitism evolved only once in the family and was retained by all members. Lindenbergia and other Orobanchaceae share the same pattern of corolla aestivation, although the pollen of Lindenbergia differs from that of the parasitic species and is more similar to nonparasitic members of Lamiales (Armstrong and Douglas, 1989; Minkin and Eshbaugh, 1989).

Parsimony analysis of $P H Y A$ data resolves four species of Lindenbergia as the sister group of the rest of the family, 
followed by clade II (Fig. 1), but this topology is not supported (50\% MPBS). The alternative topology from the ML analysis (Fig. 2), in which Lindenbergia and clade II are sister taxa and form the first branch of the family, also receives low bootstrap support (67\% MLBS). Topology tests indicate that neither topology can be rejected by the data. The exact relationship between clades I and II therefore remains unresolved in this study, but PHYA data provide the first strong evidence that clade II is one of the earliest diverging branches of the family. Moreover, the PHYA data provide new insight into the relatives of the monotypic Schwalbea americana. A close relationship among Bungea, Cymbaria, Monochasma, Schwalbea, and Siphonostegia had been suggested by earlier taxonomists (e.g., Bentham, 1876; Franchet and Savatier, 1879; Hedge, 1979a, b; Greuter, 1987), but until the PHYA study, they had not been included in any of the molecular phylogenetic studies. All five genera of clade II are species poor and have disjunct distributions. Schwalbea is monotypic and is restricted to the southeastern United States (Musselman and Mann, 1977), while Bungea, with two species, occurs in Iran, Turkey, and central Asia (Hedge, 1979b). The three other genera have Asian or disjunct distributions-Cymbaria with four species in the Ukraine, Russia, Mongolia, and China (Golubkova, 1955); Monochasma, with two species from Japan and central China (Yamazaki, 1993); and Siphonostegia, with two species in China, Korea, Taiwan, and Japan (Kusano, 1908; Yamazaki, 1993), and one in the Mediterranean (Hedge, 1979a) - the last sometimes treated as a separate genus Lesquereuxia. Schwalbea americana is federally listed as endangered. Its position at the base of the Orobanchaceae tree, in a small clade with Asian and Mediterranean species, highlights its importance as a resource of unique genetic diversity in the family.

The distribution of holoparasitism in OrobanchaceaeThe PHYA tree indicates that the split of clade III (Orobanche and its holoparasitic relatives) from the rest the family predates the major diversification of hemiparasites. Clade III contains ca. 195 species and is by far the most species-rich group of holoparasites in Orobanchaceae. Orobanche, the largest genus, is monophyletic and is sister to a clade that includes Boschniakia, Conopholis, and Epifagus. This conflicts with both the plastid (Young et al., 1999) and ITS (Wolfe et al., 2005) trees, in which Orobanche is not monophyletic. The PHYA sequences are more informative about relationships in clade III than are the ITS data (Wolfe et al., 2005), suggesting that expanded sampling of PHYA data from this clade may prove useful in placing genera such as Cistanche Hoffmans. \& Link and Diphelypaea Nicolson, which are unresolved in the plastid (Young et al., 1999) and the ITS (Schneeweiss et al., 2004a; Wolfe et al., 2005) trees.

Other transitions to holoparasitism in the family have occurred in clades V and VI. The partial or complete loss of photosynthetic ability has occurred several times within clade VI. Hyobanche and Aeginetia are entirely heterotrophic, whereas genera such as Striga and Alectra have reduced photosynthetic capacity (de la Harpe et al., 1981; Graves et al., 1992). In contrast, Lathraea, in clade V, is the only European genus that is entirely holoparasitic. Tozzia alpina may represent a transitional state between hemi- and holoparasitism. It has a prolonged holoparasitic subterranean phase of up to 10 years, but when the plant emerges it becomes photosynthetic (Weber, 1973).
Phylogenetic relationships of the hemiparasites-The majority of Orobanchaceae are herbaceous hemiparasites. A notable exception is Brandisia, a large, woody shrub from Asia (Rehder, 1913; Li, 1947) that is sister to clades IV, V, and VI. Brandisia was placed in the tribe Cheloneae (Scrophulariaceae), but some speculated that it belonged in other families, including Loganiaceae, Solanaceae, Bignoniaceae, Pedaliaceae, Myoporaceae, and Verbenaceae ( $\mathrm{Li}, 1947)$. Its parasitic nature, although mentioned by Rehder (1913), apparently was not considered strong evidence of a close relationship with hemiparasitic Scrophulariaceae. A recent phylogenetic analysis by Oxelman et al. (2005) also showed Brandisia to be a member of Orobanchaceae. While woodiness is rare in the family, the PHYA tree confirms that Radamaea and Xylocalyx also belong in Orobanchaceae. Radamaea is a large, woody shrub from Madagascar (Hemsley, 1913) and Xylocalyx is a subshrub with woody calyces from Socotra and Somalia (Thulin, 1987; Miller and Morris, 2004). Bentham (1876) suggested that Paulownia and Wightia Wall. may be close relatives of Brandisia, but this has not been supported by molecular analyses (e.g., Olmstead et al., 2001) including the present study. Sampling of additional, as yet unsampled, genera will be required to determine whether Brandisia is as isolated from other Orobanchaceae as current results suggest.

Clade IV is composed of strictly hemiparasitic taxa and contains two of the largest genera in Orobanchaceae: Pedicularis, with up to 800 species from the northern hemisphere (Mill, 2001), and Castilleja, with up to 200 species, predominantly from North and South America (Chuang and Heckard, 1991). Pedicularis is monophyletic and sister to the rest of this clade. Based on the limited sample of species in this study, species relationships within Pedicularis exhibit a strong geographical pattern, with $P$. kerneri, $P$. julica, $P$. tuberosa, and $P$. foliosa from Europe sister to $P$. kansuensis, $P$. gyrorhyncha, and $P$. densispica from Asia, consistent with the phylogeny of Ree (2005).

Most relationships within the rest of clade IV receive a high level of support. Phtheirospermum japonicum is strongly supported as sister of a clade comprising Agalinis, Aureolaria, Castilleja, Orthocarpus, Esterhazya, Cordylanthus, Lamourouxia, and Seymeria (100\% MPBS, 95\% MLBS). The position of Phtheirospermum in an ITS + matK tree (Ree, 2005) is not resolved, and it has not been included in other published analyses. Despite the widespread occurrence of polyploidy in Castilleja, with polyploid series from $4 x$ to $12 x$ (Heckard, 1968; Heckard and Chuang, 1977), we found evidence of only two divergent PHYA copies in Castilleja. The PHYA phylogeny suggests that they may have resulted from a gene duplication early in the history of the Castillejinae. Relationships among genera of the Castillejinae are not completely consistent with relationships inferred in the extensive tribal level analyses of plastid and nuclear ribosomal DNA; specifically, the position of Castilleja lasiorhynca, of the annual species $C$. tenuis, $C$. rubicundula, $C$. exserta, and of Triphysaria conflict with the Castillejinae tree (D. C. Tank and R. G. Olmstead, University of Washington, unpublished data). This may result from a combination of long branches to the annual taxa (including Triphysaria) and our much more limited taxonomic sampling. Lamourouxia and the newly sampled Esterhazya are identified as members of the clade that includes Seymeria, Agalinis, and Aureolaria. Aureolaria is sister to Seymeria, consistent with plastid data (Neel and Cummings, 2004). Ernst (1972) was unable to suggest a close relative for 
Lamourouxia from a study of its morphology, and the rps2 analysis of Young et al. (1999) did not resolve its closest relative from among the Castillejinae. Esterhazya, a small genus from Brazil, Bolivia, and Paraguay, is sister to Agalinis, which is consistent with the high degree of morphological similarity between the two genera (Barringer, 1985).

The PHYA tree contains most of the genera that likely comprise clade V; Hedbergia Molau, Nothobartsia Bolliger \& Molau and the four segregate genera of Odontites (Macrosyringion Rothm., Odontitella Rothm., Bornmuellerantha Rothm., and Bartsiella Bolliger) (Rothmaler, 1943; Bolliger, 1992), are putative members that remain unsampled. The phylogeny of the multiple $P H Y A$ copies found in some species of clade $\mathrm{V}$ is consistent with a history of gene or genome duplication. The split of $\mathrm{V}_{\mathrm{a}}$ and $\mathrm{V}_{\mathrm{b}}$ indicates a gene/ genome duplication early in the history of clade $\mathrm{V}$, with later duplications/doublings occurring in Lathraea and Euphrasia. The hexaploid number of Lathraea (Gates and Latter, 1927) is consistent with such a scenario. It is possible that the clade $\mathrm{V}_{\mathrm{b}}$ genera have a PHYA that is closely related to Lathraea PHYA \#3 and Bartsia alpina \#2, but it is also possible that this copy has been silenced, a well-documented process in polyploids (e.g., Adams and Wendel, 2005) and the expected fate of duplicate genes (Walsh 1995; Lynch and Connery, 2000). Within clade $\mathrm{V}_{\mathrm{b}}$, species relationships are well supported and are consistent with results from other analyses. Melampyrum is monophyletic and, consistent with the ITS and plastid trees (Young et al., 1999; Olmstead et al., 2001; Wolfe et al., 2005), is sister to the remaining species. However, in contrast to the ITS tree (Wolfe et al., 2005), Lathraea and Rhinanthus are unambiguously resolved as sister taxa, with the Eurasian genus Rhynchocorys as their sister taxon. Bartsia alpina, an enigmatic species that was placed in its own section of Bartsia by Molau (1990), is sister to these three genera. A second major clade of mostly European genera that is well supported by the PHYA data includes Bartsia (except $B$. alpina), Odontites, Parentucellia, Tozzia, and Euphrasia. Both Bartsia ( 49 species; Molau, 1990) and Euphrasia ( $\sim 350$ species; Fischer, 2004) are broadly distributed, occurring in both the New and Old World and in both the northern and southern hemispheres. Phytochrome data support the monophyly of Euphrasia, but Parentucellia is nested within Bartsia. Denser sampling will be required to resolve relationships of $B$. alpina with the other European and Andean Bartsia species and with allied genera such as Hedbergia from Africa, regarded as a primitive member of the group by Molau (1988), and the European Nothobartsia (Bolliger and Molau, 1992). Pseudobartsia D.Y. Hong is probably not related to Bartsia, but may be related to Phtheirospermum (Deyuan et al., 1998).

The PHYA tree unites clade V with clade VI (99\% MPBS, $82 \%$ MLBS). Several of the genera belonging to clade VI, of mostly tropical to subtropical distribution, have not been included in any previous molecular analysis. Our results confirm that the African genera Xylocalyx, Radamaea, and Nesogenes, the latter having been placed in Nesogenaceae (Marais, 1981), are members of Orobanchaceae. Radamaea from Madagascar is sister to Nesogenes, a genus of one species in Tanzania and seven species confined to islands in the South Pacific and Indian Ocean (Marais, 1981), which accords with Hemsley (1913), who noted a similarity in habit in the genera. Cyclocheilon, another African genus of uncertain affinity (Marais, 1981), has also recently been identified as a member of Orobanchaceae (Oxelman et al., 2005), but its placement within the family was not determined and we did not have the material necessary to include it in the PHYA study. It has three species from Somalia and Ethiopia (Marais, 1981) and may therefore also be a member of clade VI. Our results also confirm that the previously unsampled South American genus Escobedia belongs in this clade. Clade VI thus represents a morphologically diverse group of tropical and subtropical lineages from both the New and Old World, with the bulk of the species in the southern hemisphere. Several of the relationships suggested by the topology of this clade are consistent with those suggested by the ITS tree (Wolfe et al., 2005). Sopubia is the sister group of the remaining genera, and Alectra and Melasma are sister genera in both the PHYA and ITS trees; the PHYA data additionally suggest that Escobedia belongs in a clade with these two genera. The placement of the Asian Aeginetia in a clade with Hyobanche is well supported by the PHYA and ITS data, as is the position of Buchnera in a clade with Striga. However, the position of Cycnium in the two trees differs in a way that cannot be accounted for by differences in taxonomic sampling, and this needs to be explored with additional data.

Few of the genera in clade VI are rich in species: Buchnera (100 species), Sopubia (40 species), and Striga (40 species) are the largest (Philcox, 1965, 1990; Hansen, 1975). Branch lengths in the clade are among the longest in the PHYA tree, and there is evidence of gene duplication in the taxa that we sampled. It is possible that the combination of small, divergent genera, gene duplication and loss, codon bias, and/or elevated rates of nucleotide evolution (discussed later) have contributed to the lack of strong support for relationships among genera in clade VI. Sampling of additional taxa that might belong to this clade should be a priority for future studies of Orobanchaceae.

Molecular evolution of phytochrome $A$ in Orobanchaceae-We detected no stop codons in any of the PHYA clones that we sequenced, most of which were approximately $1.8 \mathrm{~kb}$ of coding sequence (half of the total coding sequence length). We also have found that Orobanchaceae PHYA sequences appear to be evolving under constraints similar to PHYA sequences in autotrophs, although selection appears to be slightly relaxed in holoparasites (J. R. Bennett and S. Mathews, unpublished manuscript). Finally, a full-length cDNA has been cloned from Orobanche minor that, when expressed in phyA null mutants of Arabidopsis, restores some phyA functions (Okazawa et al., 2005; Trakulnaleamsai et al., 2005). These observations suggest that while some phytochrome-mediated responses in holoparasites are lost or altered, retention of a functional phyA is important for their survival. They also suggest that the transition to parasitism involves modifications in light-signaling pathways and that further studies of Orobanche phytochromes will bear on our understanding of the mechanisms that underlie physiological changes that take place during this transition.

The discovery of novel introns in PHYA sequences in some species of Orobanchaceae was unexpected. Phytochrome gene structure is generally well conserved across land plants and coding sequences are usually interrupted by three introns. Exceptions include $P H Y$ of the green alga Mesotaenium caldariorum (Lagerh.) Hansg. with 11 introns (Lagarias et al., 1995) and PHYC of Arabidopsis thaliana, which lacks intron III (Cowl et al., 1994). One of the Orobanchaceae introns, intron $\mathrm{A}$, was found in clades II and V, a distribution 
that, along with their low sequence similarity, suggests independent gain in these two clades, despite their identical position of insertion into the coding sequence.

As noted, we found evidence of gene or genome duplication in clades IV, V, and VI. This is not unexpected given the documentation of polyploidy in the family, including in Aeginetia (Schneeweiss and Weiss, 2003), Castilleja (Heckard and Chuang, 1977), Euphrasia (Barker et al., 1988), Lathraea (Gates and Latter, 1927), Odontites (Bolliger et al., 1990), Orobanche (Schneeweiss et al., 2004b), Orthocarpus (Chuang and Heckard, 1982), and Striga (Iwo et al., 1993). Nonetheless, the species phylogenies suggested by the topologies of the PHYA clades are consistent with other lines of evidence. While the topology of the gene tree could result from differential gene silencing (Adams et al., 2003; Lai et al., 2004; Adams and Wendel, 2005) following a whole-genome duplication event that predated the origin of Orobanchaceae (Aagaard et al., 2005), the pattern also is consistent with more recent single gene duplication, segmental, or genome-doubling events.

Significant rate heterogeneity was observed among lineages in maximum likelihood analyses using PAML (Yang, 1997) (J. R. Bennett and S. Mathews, unpublished manuscript). Increases in substitution rates are found in the branch leading to clade VI, in several branches within this clade, and in the branch leading to the small clade of duplicate $P H Y A$ sequences from Lathraea clandestina, L. squamaria, and Bartsia alpina. While clade VI is not species-rich compared with other clades of Orobanchaceae, it encompasses the greatest degree of diversity in habit and morphology. It thus would be interesting to determine whether this diversity is correlated with a more general, genome-wide elevation in rates of genetic change (e.g., Barraclough and Savolainen, 2001; Webster et al., 2003). Additionally, clade VI is characterized by a significant increase in codon bias compared with the rest of the family (J. R. Bennett and S. Mathews, unpublished manuscript). Codon bias can have a major effect on the molecular evolution of proteins (Singer and Hickey, 2000) and may also confound the reconstruction of phylogeny (Lockhart et al., 1992; Foster and Hickey, 1999; Mooers and Holmes, 2000; Inagaki et al., 2004; Christianson, 2005) and is often correlated with reduced rates of synonymous substitution. The unusual combination of elevated rates of nucleotide evolution and codon bias in clade VI may have implications for functional divergence in phyA of members of this clade.

Conclusions-PHYA sequences have provided a robust hypothesis of phylogenetic structure within Orobanchaceae, based on the most extensive sampling of genera to date. The tree places all genera within well-supported major clades and identifies relationships among these clades. In several cases, including Pedicularis and Orobanche, it appears that PHYA data will be useful for resolving relationships within genera. The extended taxon sampling of this study reveals the composition of the earliest diverging lineage of hemiparasites and highlights the instability in the position of the root. This has important implications for the evolution of parasitism and represents a result that needs to be explored with additional sampling of characters and taxa. Furthermore, despite the high levels of both MP and ML bootstrap support for relationships in the PHYA tree, which are consistent with results from previous molecular analyses, it is a single gene tree that needs to be tested with additional data.

\section{LITERATURE CITED}

Aagaard, J. E., R. G. Olmstead, J. H. Willis, and P. C. Phillips. 2005. Duplication of floral regulatory genes in the Lamiales. American Journal of Botany 92: 1284-1293.

Abu Sbaih, H. A., D. M. Keith-Lucas, and S. L. Jury. 1994. Pollen morphology of the genus Orobanche L. (Orobanchaceae). Botanical Journal of the Linnean Society 116: 305-313.

Adams, K. L., R. Cronn, R. Percifield, and J. F. Wendel. 2003. Genes duplicated by polyploidy show unequal contributions to the transcriptome and organ-specific reciprocal silencing. Proceedings of the National Academy of Sciences, USA 100: 4649-4654.

Adams, K. L., AND J. F. Wendel. 2005. Polyploidy and genome evolution in plants. Current Opinion in Plant Biology 8: 135-141.

Armstrong, J. E., AND A. W. Douglas. 1989. The ontogenetic basis for corolla aestivation in Scrophulariaceae. Bulletin of the Torrey Botanical Club 116: 378-389.

Barbrook, A. C., C. J. Howe, and S. Purton. 2006. Why are plastid genomes retained in non-photosynthetic organisms? Trends in Plant Science 11: 101-108.

Barker, W. R., M. Kiehn, And E. Vitek. 1988. Chromosome numbers in Australian Euphrasia (Scrophulariaceae). Plant Systematics and Evolution 158: 161-164.

Barraclough, T. G., and V. Savolainen. 2001. Evolutionary rates and species diversity in flowering plants. Evolution 55: 677-683.

BARRINGER, K. 1985. Two new species of Esterhazya (Scrophulariaceae) from Brazil. Brittonia 37: 195-198.

BellinI, R. 1907. Criteri per una nuova classificazione della Personatae (Scrophulariaceae et Rhinanthaceae). Annali di Botanica 6: 131-145.

Bentham, G. 1846. Scrophulariaceae. In A. DeCandolle [ed.], Prodromus 10: 180-586. Victorius Masson, Paris, France.

Bentham, G. 1876. Scrophulariaceae. In G. G. Bentham and J. D. Hooker [eds.], Genera plantarum, vol. 2, 913-980. Reeve \& Co., London, UK.

BOESHORE, I. 1920. The morphological continuity of Scrophulariaceae and Orobanchaceae. Contributions of the Botanical Laboratory of the University of Pennsylvania 5: 139-177.

Bolliger, M. 1992. Monographie der Gattung Odontites (Scrophulariaceae) sowie der verwandten Gattungen Macrosyringion, Odontitella, Bornmuellerantha und Bartsiella. Willdenowia 26: 37-168.

Bolliger, M., and U. Molau. 1992. Nothobartsia, a new genus of Scrophulariaceae from south-west Europe. Plant Systematics and Evolution 179: 59-71.

Bolliger, M., J. Terrisse, And G. Heubl. 1990. On the allopolyploid origin and the distribution of Odontites jaubertianus (Bor.) D. Dietr. Botanische Jahrbücher für Systematik, Pflanzengeschichte und Pflanzengeographie 112: 1-27.

BRÜHL, P. 1920. On the systematic position of Lindenbergia, Lehmann. Journal of the Department of Science, University of Calcutta 2: 1116.

Bungard, R. A. 2004. Photosynthetic evolution in parasitic plants: insight from the chloroplast genome. Bioessays 26: 235-247.

Christianson, M. L. 2005. Codon usage patterns distort phylogenies from or of DNA sequences. American Journal of Botany 92: 1221-1233.

Chuang, T. I., and L. R. Heckard. 1982. Chromosome numbers of Orthocarpus and related monotypic genera (Scrophulariaceae: subtribe Castillejinae). Brittonia 34: 89-101.

Chuang, T. I., And L. R. HeCKard. 1991. Generic realignment and synopsis of subtribe Castillejinae (Scrophulariaceae-tribe Pediculareae). Systematic Botany 16: 644-666.

Clack, T., S. Mathews, and R. A. Sharrock. 1994. The phytochrome apoprotein family in Arabidopsis is encoded by five genes: the sequences and expression of PHYD and PHYE. Plant Molecular Biology 25: 413-427.

Cowl, J. S., N. Hartley, D. X. Xie, G. C. Whitelam, G. P. Murphy, and N. P. Harberd. 1994. The PHYC gene of Arabidopsis. Plant Physiology 106: 813-814.

Davis, C. C., C. D. Bell, P. W. Fritsch, and S. Mathews. 2002. Phylogeny of Acridocarpus-Brachylophon (Malpighiaceae): implica- 
tions for tertiary tropical floras and Afroasian biogeography. Evolution 56: 2395-2405.

DeBry, R. W., and R. G. Olmstead. 2000. A simulation study of reduced tree-search effort in bootstrap resampling analysis. Systematic Biology 49: 171-179.

de la Harpe, A. C., J. H. Visser, and N. Grobbelaar. 1981. Photosynthetic characteristics of some South African parasitic flowering plants. Zeitschrift fuer Pflanzenphysiologie 103: 265-275.

DePamphilis, C. W. 1995. Genes and genomes. In M. C. Press and J. D. Graves [eds.], Parasitic plants, 177-205. Chapman \& Hall, London, UK.

DePamphilis, C. W., And J. D. Palmer. 1990. Loss of photosynthetic and chlororespiratory genes from the plastid genome of a parasitic flowering plant. Nature 348: 337-339.

dePamphilis, C. W., N. D. Young, and A. D. Wolfe. 1997. Evolution of plastid gene rps2 in a lineage of hemiparasitic and holoparasitic plants: many losses of photosynthesis and complex patterns of rate variation. Proceedings of the National Academy of Sciences, USA 94: 7367-7372.

Deyuan, H., Y. Handi, J. Cunli, And N. H. Holgren. 1998. Scrophulariaceae. In W. Zhengyi and P. H. Raven [eds.], Flora of China, vol. 18, 1-212. Missouri Botanical Garden Press, St. Louis, Missouri, USA.

Duvall, M., S. Mathews, N. A. Mohammad, and T. Russell. In press. Placing the monocots; conflicting signal from trigenomic analyses. In J. T. Columbus, E. A. Friar, J. M. Porter, L. M. Prince, and M. G. Simpson [eds.], Monocots: comparative biology and evolution, vol. 1, 77-88. Rancho Santa Ana Botanic Garden, Claremont, California, USA.

ERNST, W. R. 1972. Floral morphology and systematics of Lamourouxia (Scrophulariaceae: Rhinanthoideae). Smithsonian Contributions to Botany 6: 1-63.

Fischer, E. 2004. Scrophulariaceae. In J. W. Kadereit [ed.], The families and genera of vascular plants, vol. 7, 333-432. Springer-Verlag, Berlin, Germany.

Foster, P. G., AND D. A. Hickey. 1999. Compositional bias may affect both DNA-based and protein-based phylogenetic reconstructions. Journal of Molecular Evolution 48: 284-290.

Franchet, A. R., AND L. SAVATIER. 1879. Enumeratio plantarum in Japonia sponte crescentium hucusque rite cognitarum, vol. 2. F. Savy, Paris, France.

Franklin, K. A., S. J. Davis, W. M. Stoddart, R. D. Vierstra, and G. C. Whitelam. 2003a. Mutant analyses define multiple roles for phytochrome C in Arabidopsis photomorphogenesis. Plant Cell 15: 1981-1989.

Franklin, K. A., U. Praekelt, W. M. Stoddart, O. E. Billingham, K. J. Halliday, and G. C. Whitelam. 2003b. Phytochromes B, D, and E act redundantly to control multiple physiological responses in Arabidopsis. Plant Physiology 131: 1340-1346.

Gates, R. R., and J. Latter. 1927. Observations on the pollen development of two species of Lathraea. Journal of the Royal Microscopical Society 1927: 209-225.

Golubkova, V. F. 1955. Cymbaria. In B. K. Schischkin and E. G. Bobrov [eds.], Flora URSS, vol. 22, 799-801. V.L. Komarov Botanical Institute of the Academy of Sciences of the U.S.S.R., Moscow, Russia.

Graves, J. D., M. C. Press, S. Smith, and G. R. Stewart. 1992. The carbon canopy economy of the association between cowpea and the parasitic angiosperm Striga gesnerioides. Plant, Cell \& Environment 15: 283-288.

Greuter, W. 1987. Some notes on Lesquereuxia (Scrophulariaceae). Botanische Jahrbücher für Systematik, Pflanzengeschichte und Pflanzengeographie 108: 251-257.

Halliday, K. J., and G. C. Whitelam. 2003. Changes in photoperiod or temperature alter the functional relationships between phytochromes and reveal roles for phyD and phyE. Plant Physiology 131: 19131920.

HALLIER, H. 1903. Ueber die abgrenzung und verwandtschaft der einzelnen sippen bei den Scrophulariaceen. Bulletin de L'Herbier Boissier, II 3: 181-207.
Hansen, O. J. 1975. The East African species of Sopubia (Scrophulariaceae). Kew Bulletin 30: 543-558.

HeCKARD, L. R. 1968. Chromosome numbers and polyploidy in Castilleja (Scrophulariaceae). Brittonia 20: 212-226.

Heckard, L. R., and T.-I. Chuang. 1977. Chromosome numbers, polyploidy, and hybridisation in Castilleja (Scrophulariaceae) of the Great Basin and Rocky Mountains. Brittonia 29: 159-172.

Hedge, I. C. 1979a. Lesquereuxia Boiss. In P. H. Davis [ed.], Flora of Turkey and the East Aegean Islands, vol. 6, 781-782. Edinburgh University Press, Edinburgh, UK.

Hedge, I. C. 1979b. Bungea C.A. Mey. In P. H. Davis [ed.], Flora of Turkey and the East Aegean Islands, vol. 6, 782-783. Edinburgh University Press, Edinburgh, UK.

Hemsley, W. B. 1913. On the genera Radamaea Bentham, and Nesogenes A. de Candolle. Journal of the Linnean Society, Botany 41: 311-316.

HJertson, M. L. 1995. Taxonomy, phylogeny and biogeography of Lindenbergia (Scrophulariaceae). Botanical Journal of the Linnean Society 119: 265-321.

Howe, G. T., P. A. Bucciaglia, W. P. Hackett, G. R. Furnier, M. M. Cordonnier-Pratt, and G. Gardner. 1998. Evidence that the phytochrome gene family in black cottonwood has one PHYA locus and two $P H Y B$ loci but lacks members of the $P H Y C / F$ and $P H Y E$ subfamilies. Molecular Biology and Evolution 15: 160-175.

Inagaki, Y., A. G. B. Simpson, J. B. Dacks, And A. J. Roger. 2004. Phylogenetic artifacts can be caused by leucine, serine, and arginine codon usage heterogeneity: dinoflagellate plastid origins as a case study. Systematic Biology 53: 582-593.

İNCEOǦLU, Ö. 1982. Pollen grains in some Turkish Rhinantheae (Scrophulariaceae). Grana 21: 83-96.

Iwo, G. A., S. W. H. Husaini, and G. O. Olaniyan. 1993. Cytological observations and distribution of Striga species in central part of Nigeria. Feddes Repertorium 104: 497-501.

KuIJ, J. 1969. The biology of parasitic flowering plants. University of California Press, Berkeley, California, USA.

Kusano, S. 1908. On the parasitism of Siphonostegia (Rhinantheae). Bulletin of the College of Agriculture, Tokyo Imperial University 8: 51-71.

Lagarias, D. M., S.-H. Wu, and J. C. Lagarias. 1995. Atypical phytochrome gene structure in the green alga Mesotaenium caldariorum. Plant Molecular Biology 29: 1127-1142.

Lai, L., J. Ma, Z. Swigoñová, W. Ramakrishna, E. Linton, V. Llaca, B. Tanyolac, Y.-J. Park, O.-Y. Jeong, J. L. Bennetzen, and J. Messing. 2004. Gene loss and movement in the maize genome. Genome Research 14: 1924-1931.

LARSEN, A. 1994. The comparison of morphological and molecular data in phylogenetic systematics. In B. Schierwater, B. Street, G. P. Wagner, and R. DeSalle [eds.], Molecular ecology and evolution: approaches and applications, 371-390. Birkhäuser, Basel, Switzerland.

Lavin, M., E. Eshbaugh, J. Hu, S. Mathews, and R. A. Sharrock. 1998. Monophyletic subgroups of the tribe Millettieae (Leguminoseae) as revealed by phytochrome nucleotide sequence data. American Journal of Botany 85: 412-433.

LI, H.-L. 1947. Relationship and taxonomy of the genus Brandisia. Journal of the Arnold Arboretum 28: 127-136.

Li, W.-Z., AND C. C. ChinnapPa. 2003. The phytochrome gene family in the Stellaria longipes complex. International Journal of Plant Sciences 164: 657-673.

Lockhart, P. J., C. J. Howe, D. A. Bryant, T. J. Beanland, and A. W. D. LARKUM. 1992. Substitutional bias confounds inference of cyanelle origins from sequence data. Journal of Molecular Evolution 34: 153162.

Lynch, M., And J. S. Connery. 2000. The evolutionary fate and consequences of duplicate genes. Science 290: 1151-1155.

MaraIs, W. 1981. Two new gamopetalous families, Cyclocheilaceae and Nesogenaceae, for extra-Australian 'Dicrastylidaceae'. Kew Bulletin 35: 797-812.

Mathews, S., and M. J. Donoghue. 1999. The root of angiosperm phylogeny inferred from duplicate phytochrome genes. Science 286: 947-950. 
Mathews, S., and M. J. Donoghue. 2000. Basal angiosperm phylogeny inferred from duplicate phytochromes A and C. International Journal of Plant Sciences 161 (6 Supplement): S41-S55.

Mathews, S., M. Lavin, and R. A. Sharrock. 1995. Evolution of the phytochrome gene family and its utility for phylogenetic analyses of angiosperms. Annals of the Missouri Botanical Garden 82: 296-321.

Mathews, S., AND R. A. Sharrock. 1996. The phytochrome gene family in grasses (Poaceae): a phylogeny and evidence that grasses have a subset of the loci found in dicot angiosperms. Molecular Biology and Evolution 13: 1141-1150.

Mathews, S., and R. A. Sharrock. 1997. Phytochrome gene diversity. Plant, Cell \& Environment 20: 666-671.

Mathews, S., R. C. Tsai, and E. A. Kellogg. 2000. Phylogenetic structure in the grass family (Poaceae): evidence from the nuclear gene phytochrome B. American Journal of Botany 87: 96-107.

Mill, R. R. 2001. Notes relating to the flora of Bhutan. XLIII. Scrophulariaceae (Pedicularis). Edinburgh Journal of Botany 58: 57-98.

Miller, A. G., AND M. Morris. 2004. Ethnoflora of the Socotra Archipelago. The Royal Botanic Garden Edinburgh, Edinburgh, UK.

Minkin, J. P., And W. H. Eshbaugh. 1989. Pollen morphology of the Orobanchaceae and rhinanthoid Scrophulariaceae. Grana 28: 1-18.

Molau, U. 1988. Hedbergia, a new genus of Scrophulariaceae from Africa. Nordic Journal of Botany 8: 193-195.

Molau, U. 1990. The genus Bartsia (Scrophulariaceae-Rhinanthoideae). Opera Botanica 102: 1-99.

Møller, S. G., P. J. Ingles, and G. C. Whitelam. 2002. The cell biology of phytochrome signalling. New Phytologist 154: 553-590.

Monte, E., J. M. Alonso, J. R. Ecker, Y. Zhang, X. Li, J. Young, S. Austin-PhILliPs, AND P. H. QuaIL. 2003. Isolation and characterization of phyC mutants in Arabidopsis reveals complex crosstalk between phytochrome signalling pathways. Plant Cell 15: 1962-1980.

Montgomery, B. L., AND J. C. Lagarias. 2002. Phytochrome ancestry: sensors of bilins and light. Trends in Plant Science 7: 357-366.

Mooers, A. Ø., and E. C. Holmes. 2000. The evolution of base composition and phylogenetic inference. Trends in Ecology and Evolution 15: 365-369.

Morden, C. W., K. H. Wolfe, C. W. dePamphilis, and J. D. Palmer. 1991. Plastid translation and transcription genes in a non-photosynthetic plant: intact, missing and pseudogenes. The European Molecular Biology Organization Journal 10: 3281-3288.

Musselman, L. J., AND W. F. Mann. 1977. Parasitism and haustorial structure of Schwalbea americana (Scrophulariaceae). Beiträge zur Biologie der Pflanzen 53: 309-315.

Neel, M. C., And M. P. Cummings. 2004. Section-level relationships of North American Agalinis (Orobanchaceae) based on DNA sequence analysis of three chloroplast gene regions. BioMed Central Evolutionary Biology 4: 15.

NickRent, D. L. 2006. The parasitic plant connection: parasitic plant genera. Department of Plant Biology, Southern Illinois University, Carbondale, Illinois, USA. Website http://www.parasiticplants.siu. edu/ListParasites.html [accessed 8 January 2006].

Nickrent, D. L., R. J. Duff, A. E. Colwell, A. D. Wolfe, N. D. Young, K. E. Steiner, and C. W. DePAmphills. 1998. Molecular phylogenetic and evolutionary studies of parasitic plants. In D. E. Soltis, P. S. Soltis, and J. J. Doyle [eds.], Molecular systematics of plants II, 211241. Kluwer, Boston, Massachusetts, USA.

Odasz, A. M., AND O. SAVOLAINEN. 1996. Genetic variation in populations of the Arctic perennial Pedicularis dasyantha (Scrophulariaceae), on Svalbard, Norway. American Journal of Botany 83: 1379-1385.

Okazawa, A., C. Trakulnaleamsai, E. Fukusaki, and A. Kobayashi. 2005. Transient expression of phytochrome A from holoparasitic Orobanche minor in Arabidopsis protoplasts. Plant and Cell Physiology 46: S45.

Olmstead, R. G., C. W. dePamphilis, A. D. Wolfe, N. D. Young, W. J. Elisons, AND P. A. ReEves. 2001. Disintegration of the Scrophulariaceae. American Journal of Botany 88: 348-361.

Oxelman, B., P. Kornhall, R. G. Olmstead, and B. Bremer. 2005. Further disintegration of Scrophulariaceae. Taxon 54: 411-425.
Philcox, D. 1965. Revision of the new world species of Buchnera L. (Scrophulariaceae). Kew Bulletin 19: 275-315.

Philcox, D. 1990. Scrophulariaceae. In E. Launert and G. V. Pope [eds.], Flora Zambesiaca, vol. 8(2), 1-179. Managing Committee for Flora Zambesiaca, Royal Botanic Gardens, Kew, London, UK.

Posada, D., and K. A. Crandall. 1998. Modeltest: testing the model of DNA substitution. Bioinformatics 14: 817-818.

ReE, R. H. 2005. Phylogeny and the evolution of floral diversity in Pedicularis (Orobanchaceae). International Journal of Plant Sciences 166: 595-613.

Rehder, A. 1913. Scrophulariaceae. In C. S. Sargent [ed.], Plantae Wilsonianae, vol. 1, 573-578. Cambridge, Massachusetts, USA.

Riches, C. R., ANd C. Parker. 1995. Parasitic plants as weeds. In M. C. Press and J. D. Graves [eds.], Parasitic plants, 226-255. Chapman \& Hall, London, UK.

Rodríguez, F., J. L. Oliver, A. Marín, and J. R. Medina. 1990. The general stochastic model of nucleotide substitution. Journal of Theoretical Biology 142: 485-502.

Rothmaler, W. 1943. Die aufspaltung von Odontites Hall. ex Zinn. Mitteilungen de Thueringischen Botanischen Vereins 50: 224-230.

Samuel, R., H. Kathriarachchi, P. Hoffmann, M. H. J. Barfuss, K. J. Wurdack, C. C. Davis, and M. W. Chase. 2005. Molecular phylogenetics of Phyllanthaceae: evidence from plastid matK and nuclear PHYC sequences. American Journal of Botany 92: 132-141.

Schneeweiss, G. M., A. Colwell, J.-M. Park, C.-G. Jang, and T. F. STUESSY. 2004a. Phylogeny of holoparasitic Orobanche (Orobanchaceae) inferred from nuclear ITS sequences. Molecular Phylogenetics and Evolution 30: 465-478.

Schneeweiss, G. M., T. Palomeque, A. E. Colwell, and H. WeissSchNeEwEISs. 2004b. Chromosome numbers and karyotype evolution in holoparasitic Orobanche (Orobanchaceae) and related genera. American Journal of Botany 91: 439-448.

SchneEweIss, G. M., AND H. WeIss. 2003. Polyploidy in Aeginetia indica L. (Orobanchaceae). Cytologia 68: 15-17.

Sharrock, R. A., T. Clack, and L. Goosey. 2003. Differential activities of the Arabidopsis phyB/D/E phytochromes in complementing phyB mutant phenotypes. Plant Molecular Biology 52: 135-142.

Sharrock, R. A., AND S. Mathews. 2006. Phytochrome genes in higher plants: structure, expression, and evolution. In E. Schafer and F. Nagy [eds.], Photomorphogenesis in plants and bacteria. Kluwer, Dordrecht, Netherlands.

Sharrock, R. A., AND P. H. QuaIl. 1989. Novel phytochrome sequences in Arabidopsis thaliana: structure, evolution, and differential expression of a plant regulatory photoreceptor family. Genes and Development 3: $1745-1757$.

Shimodaira, H., and M. Hasegawa. 1999. Multiple comparisons of loglikelihoods with applications to phylogenetic inference. Molecular Biology and Evolution 16: 1114-1116.

Simmons, M. P., C. C. Clevinger, V. Savolainen, R. H. Archer, S. Mathews, And J. J. Doyle. 2001. Phylogeny of the Celastraceae inferred from phytochrome B gene sequences and morphology. American Journal of Botany 88: 313-325.

Singer, G. A. C., AND D. A. HickeY. 2000. Nucleotide bias causes a genomewide bias in the amino acid composition of proteins. Molecular Biology and Evolution 17: 1581-1588.

Sмгтн, H. 2000. Phytochromes and light signal perception by plants-an emerging synthesis. Nature 407: 585-591.

Swofford, D. L. 2002. PAUP*: phylogenetic analysis using parsimony (*and other methods), version 4. Sinauer, Sunderland, Massachusetts, USA.

Thulin, M. 1987. A new species of Xylocalyx (Scrophulariaceae) from Somalia. Nordic Journal of Botany 7: 267-269.

Trakulnaleamsai, C., A. Okazawa, C.-L. An, S. Kajiyama, E. Fukusaki, K. Yoneyama, Y. Takeuchi, and A. Kobayashi. 2005. Isolation and characterisation of a cDNA encoding phytochrome A in the nonphotosynthetic parasitic plant, Orobanche minor Sm. Bioscience, Biotechnology and Biochemistry 69: 71-78.

von Wettstein, R. 1891. Scrophulariaceae. In A. Engler and K. Prantl 
[eds.], Die Natürlichen Pflanzenfamilien, vol. 4, part 3b, 39-107. Wilhelm Engelmann, Leipzig, Germany.

WALSH, J. B. 1995. How often do duplicated genes evolve new functions? Genetics 139: 421-428.

Weber, H. C. 1973. Zur biologie von Tozzia alpina L. (Standort, Wirtspflanzen, Entwicklung und Parasitismus). Beitrage zur Biologie der Pflanzen 49: 237-249.

Webster, A. J., R. J. Payne, and M. Pagel. 2003. Molecular phylogenies link rates of evolution and speciation. Science 301: 478.

Wimpee, C. F., R. Morgan, and R. L. Wrobel. 1992. Loss of transfer RNA genes from the plastid 16S-23S ribosomal RNA gene spacer in a parasitic plant. Current Genetics 21: 417-422.

Wimpee, C. F., R. L. Wrobel, and D. K. Garvin. 1991. A divergent plastid genome in Conopholis americana, an achlorophyllous parasitic plant. Plant Molecular Biology 17: 161-166.

Wolfe, A. D., and C. W. DePamphilis. 1998. The effect of relaxed functional constraints on the photosynthetic gene $r b c L$ in photosynthetic and nonphotosynthetic parasitic plants. Molecular Biology and Evolution 15: 1243-1258.

Wolfe, A. D., C. P. Randle, L. Liu, and K. E. Steiner. 2005. Phylogeny and biogeography of Orobanchaceae. Folia Geobotica 40: 115-134.

Wolfe, K. H., D. S. Katz-Downie, C. W. Morden, and J. D. Palmer. 1992a. Evolution of the plastid ribosomal RNA operon in a nongreen parasitic plant: accelerated sequence evolution, altered promoter structure, and tRNA pseudogenes. Plant Molecular Biology 18: $1037-1048$.

Wolfe, K. H., W.-H. Li, and P. M. Sharp. 1987. Rates of nucleotide substitution vary greatly among plant, mitochondrial, chloroplast, and nuclear DNAs. Proceedings of the National Academy of Sciences, USA 84: 9054-9058.
Wolfe, K. H., C. W. Morden, S. C. Ems, And J. D. Palmer. 1992b. Rapid evolution of the plastid translational apparatus in a nonphotosynthetic plant: loss or accelerated sequence evolution of tRNA and ribosomal protein genes. Journal of Molecular Evolution 35: 304-317.

Wolfe, K. H., C. W. Morden, and J. D. Palmer. 1992c. Small single-copy region of plastid DNA in the non-photosynthetic angiosperm Epifagus virginiana contains only two genes: differences among dicots, monocots and bryophytes in gene organization at a nonbioenergetic locus. Journal of Molecular Biology 223: 95-104.

Wolfe, K. H., C. W. Morden, and J. D. Palmer. 1992d. Function and evolution of a minimal plastid genome from a nonphotosynthetic parasitic plant. Proceedings of the National Academy of Sciences, USA 89: 10648-10652.

YAMAZAKI, T. 1993. Scrophulariaceae. In K. Iwatsuki, T. Yamazaki, D. E. Boufford, and H. Ohba [eds.], Flora of Japan, vol. 3a, 326-374. Kodansha, Japan.

YANG, Z. 1997. PAML: a program for phylogenetic analysis by maximum likelihood. Computer Applications in the Biosciences 13: 555-556.

Young, N. D., AND C. W. DEPAMPHILIS. 2000. Purifying selection detected in the plastid gene matK and flanking ribozyme regions within a group II intron of nonphotosynthetic plants. Molecular Biology and Evolution 17: 1933-1941.

Young, N. D., AND C. W. DEPAMPhILIs. 2005. Rate variation in parasitic plants: correlated and uncorrelated patterns among plastid genes of different functions. BioMed Central Evolutionary Biology 5: 16.

Young, N. D., K. E. Steiner, And C. W. DePamphilis. 1999. The evolution of parasitism in Scrophulariaceae/Orobanchaceae: plastid gene sequences refute an evolutionary transition series. Annals of the Missouri Botanical Garden 86: 876-893.

APPENDIX. Species sampled, voucher specimens and intron lengths for taxa included in this study. $-=\mathrm{cDNA}$ sequence; $\mathrm{n} / \mathrm{s}=\mathrm{intron}$ not sequenced because fragment was amplified with primers that do not span the intron region; * sequence obtained from GenBank.

Taxon-GenBank accession number; Voucher specimen; Intron length (bp): Intron A, Intron B, Intron I.

Aeginetia indica L.-AM233920; dePamphilis 95.21 (PAC); absent, absent, n/s. Agalinis fasciculata Raf. -AM233921; Henderson 671671 (UMO); absent, absent, n/s. A. purpurea Pennell—AM233922; Mathews $395(\mathrm{GH})$; absent, absent, n/s. Ajuga reptans L.AM233923; Bennett 75 (GH); absent, absent, 110. Alectra sessiliflora Kuntze-AM233924; Steiner 3261 (NBG); absent, absent, 557. Alonsoa sp.-AM237453; Wood 18362 (K); absent, absent, 102. Aptosimum pumilum Benth.-AM233925; Miller 16135 (E); absent, absent, 199. Aureolaria pedicularia (L.) Raf.-AM233926; Mathews 396 (GH); absent, absent, 801.

Bartsia alpina L. \#1-AM233928; Krajesk s.n. (LJU); 517, absent, n/s. B. alpina L. \#2-AM233929; Krajesk s.n. (LJU); n/s, absent, 181. B. crenata Molau-AM233927; Wood 17840 (K); 500, absent, 316. B. trixago L.-AM233930; Bennett 60 (FHO); 498, absent, 313. Boschniakia hookeri Walpers-AM233931; Colwell AC-96-WA-CB1 (WTU); absent, absent, 408. B. rossica (Cham. \& Schltdl.) B. Fedtsch-AM233932; Colwell s.n. (WTU); absent, absent, 474. B. strobilacea A. Gray-AM233933; Wolfe 530 (OS); absent, absent, 409. Brandisia hancei Hook. f.-AM233934, AM234037; Liu 15358 (GH); absent, absent, 612. Buchnera floridana Gand.-AM233935; Allison \& Gohlson 4452 (UGA); absent, absent, n/s. Bungea trifida C.A. Mey.-AM233936; Schneeweiss TR0215 (WU); 249, 346, 414.

Castilleja coccinea (L.) Sprengel-AM233938; Bennett s.n. (GH); absent, absent, 659. C. crista-galli Rydb.-AM233937; Mathews 036-3 (MONT); absent, absent, 996. C. exserta (A. Heller) T.I. Chuang \& Heckard-AM233939; Tank 2002-06 (WTU); absent, absent, 254. C. fissifolia Sessé \& Moç.-AM233944; Wood 17842 (K); absent, absent, 997. C. lasiorhyncha (A. Gray) T.I. Chuang \& L.R. HeckardAM233940; Beardsley 98-027 (WTU); absent, absent, n/s. C. miniata Hook.-AM233941; Mathews 319-2 (MONT); absent, absent, 997. C. rubicundula (Jepson) T.I. Chuang \& L.R. Heckard-AM233942; Tank 2002-12 (WTU); absent, absent, 856. C. sp.-AM233943; Wolfe 532 (OS); absent, absent, 704. C. sulphurea Rydb. \#1-AM233945;
Garrigan 95-CO-MRS-1 (WTU); absent, absent, 537. C. sulphurea Rydb. \#2-AM233946; Garrigan 95-CO-MRS-1 (WTU); absent, absent, n/s. C. tenuis (A. Heller) T.I. Chuang \& HeckardAM233947; Egger 1235 (UMO); absent, absent, 783. Chelone obliqua L.-AM233948; Yatskievych 02-74 (MO); absent, absent, 89. Conopholis alpina Liebm.-AM233949; Colwell 89-NMCC-6 (WTU); absent, absent, 380. C. americana (L.) Wallr. f.-AM233950; Colwell 89-IN-CCF (WTU); absent, absent, 362. Cordylanthus ramosus Nutt.-AM233951; Knoke 174 (UMO); absent, absent, 932. Cycnium adonense Benth.-AM233952; Steiner 3262 (NBG); absent, absent, 441. Cymbaria mongolica Maxim-AM233953, AM234038; Liu \& Zhang 930014 (MO); 248, 498, n/s.

Epifagus virginiana Bärl.-AM233954, AM234039; Mathews (GH); absent, absent, n/s. Escobedia grandiflora Kuntze \#1-AM233955; Wood 18304 (K); absent, absent, 694. E. grandiflora Kuntze \#2AM233956; Wood 18304 (K); absent, absent, 203. Esterhazya campestris Mart.-AM233957; Wood 20161 (K); absent, absent, 1147. Euphrasia alsa F. Muell._AM233958; Zich 220 (GH); 219 , absent, 319. E. collina R. Br.-AM233959; Zich 209 (GH); 170, absent, 321. E. regelii Wettst.-AM233960; Ho et al. 1741 (GH); 173 , absent, 264. E. stricta J.F. Lehm. \#1-AM233961; Douglas et al. 2174 (GH); 490, absent, 261. E. stricta J.F. Lehm. \#2-AM233962; Douglas et al. $2174(\mathrm{GH}) ; 188$, absent, n/s.

Glechoma hederacea L.-AM233963; Bennett 76 (GH); absent, absent, 125.

Hyobanche atropurpurea Bolus-AM233964; Wolfe 1010-2 (OS); absent, absent, 733. H. glabrata Hiern-AM233965; Wolfe 945-1 (OS); absent, absent, 727. H. rubra N.E. Br.-AM233966; Wolfe 976 (OS); absent, absent, 735. H. sanguinea L.-AM233967; Wolfe 932-4 (OS); absent, absent, 700.

Lamium purpureum L.-AM233968; Bennett 74 (GH); absent, absent, 331. Lamourouxia rhinanthifolia Kunth-AM233969; Egger 1190 (UMO); absent, absent, 1027. Lathraea clandestina L. \#1- 
AM233970; Bennett 57 (FHO); 547, absent, n/s. L. clandestina L. \#2-AM233971; Bennett 57 (FHO); 411, absent, 318. L. clandestina L. \#3-AM233972, AM234040; Bennett 57 (FHO); 283, absent, 137. L. squamaria L. \#1-AM233973; Frajman s.n. (LJU); 298, absent, 325. L. squamaria L. \#2-AM233974; Frajman s.n. (LJU); 515, absent, 317. L. squamaria L. \#3-AM233975; Frajman s.n. (LJU); $\mathrm{n} / \mathrm{s}, \mathrm{n} / \mathrm{s}$, 137. Lindenbergia indica (L.) Vatke-AM233976, AM234041; Dickason 5437 (GH); absent, absent, 291. L. muraria (Roxb.) Brühl-AM233977; Grierson \& Long 2312 (E); absent, absent, 290. L. philippensis (Cham. \& Schltd.) Benth.-AM233978; Armstrong 1163 (ISU); absent, absent, 696. L. sokotrana Vierh.AM233918; Miller 1127 (E); absent, absent, n/s.

Melampyrum arvense L.-AM233919; Schneeweiss 1317/02 (WU); 257, absent, 103. M. carstiense Fritsch-AM233979; Krajsek s.n. (LJU); 257, absent, 243. M. nemorosum L.-AM233980; Braystatler 96M37-1 (RNG); 97, absent, 72. M. pratense L.-AM233981; Nyffler s.n. (GH); 253, absent, 306. M. sylvaticum L.-AM233982; Krajsek s.n. (LJU); 88, absent, 72. Melasma scabrum P.J. Bergius \#1AM233983; Steiner 3496 (CAS); absent, absent, n/s. M. scabrum P. J. Bergius \#2-AM233984; Steiner 3496 (CAS); absent, absent, 323. Monochasma sheareri Franch. \& Sav.-AM233985, AM234042; Ye 3921 (MO); 227, 108, 175.

Nesogenes africanus G. Taylor-AM233986; Bidgood 2063 (MO); absent, absent, n/s. N. dupontii Hemsl.-AM233987; Jongkind 968 (MO); absent, absent, $\mathrm{n} / \mathrm{s}$.

Odontites himalayicus Pennell-AM233988; Webster 6290 (GH); 507, absent, 307. Orobanche californica Cham. \& Schltdl.-AM233989; Colwell AC-97-CA-BLO (WTU); absent, absent, 503. O. corymbosa (Rydb.) Ferris-AM233990; Leidholf s.n. (WTU); absent, absent, 559. O. densiflora Reut.-AM233991; Bennett 65 (FHO); absent, absent, 566. O. fasciculata Nutt.-AM233992; Beardsley s.n. (WTU); absent, absent, 494. O. gracilis Sm.-AM233993; Bennett 82 (GH); absent, absent, n/s. O. pinorum Geyer-AM233994; Colwell AC96-WA-LC (WTU); absent, absent, n/s. O. raddeana Beck-AM233995; Schneeweiss 342 (WU); absent, absent, 613. O. ramosa L.AM233996; Hughes 2191 (FHO); absent, absent, 574. Orthocarpus bracteosus Benth.-AM233997; Wolfe 571 (OS), absent; absent, 947. O. tenuifolius A. Gray-AM233998, AM234043; Lavin 72892 (MONT); absent, absent, 628.

Parentucellia latifolia (L.) Caruel-AM233999; Jury 18765 (RNG); 484, absent, 312. P. viscosa (L.) Caruel-AM234000; Bennett 66 (FHO); 490, absent, 312. Paulownia tomentosa (Thunb.) Steud.-AM234001; Olmstead 88-008 (WTU); absent, absent, 172. Pedicularis densispica Maxim-AM234002; Boufford et al. $28416(\mathrm{GH})$; absent, absent, 899.
P. foliosa L.-AM234003; dePamphilis s.n.; absent, absent, 971. P. gyrorhyncha Maxim-AM234004; Boufford et al. 28435 (GH); absent, absent, 896. P. julica E. Mayer-AM234005; Krajsek s.n. (LJU); absent, absent, 896. P. kansuensis Maxim-AM234006; Boufford et al. $27695(\mathrm{GH})$; absent, absent, 889. P. kerneri Dalla Torre-AM234007; Nyffler s.n. (GH); absent, absent, 819. P. tuberosa L.-AM234008; Nyffler s.n. (GH); absent, absent, 817. Penstemon cobaea Pennell-AM234009; Bennett 77 (GH); absent, absent, 460. Phtheirospermum japonicum (Thunb.) Kanitz-AM234010; Tsugaru \& Sawada 28464 (GH); absent, absent, 857.

Radamaea montana Benth.-AM234011, AM234044; Rakutamalaza 1304 (MO); absent, absent, n/s. Rhinanthus alectorolophus (Scop.) Pollich-AM234012; Nyffler s.n. (GH); 264, absent, 290. R. freynii Fiori-AM234013; Bennett $88(\mathrm{GH})$; 305, absent, 302. R. glacialis Personn.-AM234014; Nyffler s.n. (GH); 298, absent, 252. R. minor L.-AM234015; Bennett 84 (GH); 359, absent, 290. Rhynchocorys orientalis Benth.-AM234016; Albach \& Schneeweiss s.n. (WU); 237, absent, 264.

Schwalbea americana L.-AM234017; Kirkman s.n. (PAC); 619, 421, 714. Scrophularia arguta Sol.-AM234018; Miller 17017A (E); absent, absent, 92. Seymeria laciniata (M. Martens \& Galeotti) Standl.-AM234019; Egger 1201 (UMO); absent, absent, n/s. Siphonostegia chinensis Benth.-AM234020; Bartholomew et al. 1435 (GH); 652, 410, n/s. Solanum tuberosum L.*-S84872; - , —. Sopubia cana Harv.-AM234021; Randle 135 (OS); absent, absent, 229. S. lanata Engl.-AM234022; Bidgood 3601 (MO); absent, absent, n/s. S. ramosa Hochst.-AM234023; Kayumbo 2752 (MO); absent, absent, 234. Striga asiatica (L.) Kuntze-AM234024; Parker 1213 (RNG); absent, absent, n/s. S. bilabiata KuntzeAM234025; Steiner 3273 (NBG); absent, absent, n/s. S. gesnerioides (Willd.) Vatke-AM234026; Jury 19619 (RNG); absent, absent, n/s. S. linearifolia (Schumach. \& Thonn.) Hepper \#1-AM234027; Bytebiers B2334 (RNG); absent, absent, 392. S. linearifolia (Schumach. \& Thonn.) Hepper \#2-AM234028; Bytebiers B2334 (RNG); absent, absent, n/s. S. orobanchoides (R. Br.) Benth.AM234029; Steiner s.n. (NBG); absent, absent, n/s. Strobilanthes attenuata Nees-AM234030; Chilterns Seeds, UK; absent, absent, 83. Tozzia alpina L.-AM234031; Bennett 87 (GH); 389, absent, 309. Triphysaria pusilla (Benth.) T.I. Chuang \& Heckard-AM234032; Colwell 92-CA-TYC (MO); absent, absent, 822.

Xylocalyx asper Balf. f. \#1-AM234033; Miller 17076 (E); n/s, n/s, n/s. X. asper Balf. f. \#2-AM234034; Miller 17076 (E); n/s, n/s, n/s. X. carterae Thulin \#1-AM234035; Wieland 4387 (MO); n/s, n/s, n/s. $X$. carterae Thulin \#2-AM234036; Wieland 4387 (MO); n/s, n/s, n/s. 